Article

\title{
Learning from Loss: Eroding Coastal Heritage in Scotland
}

\author{
Ellie Graham *, Joanna Hambly and Tom Dawson
}

School of History, University of St Andrews, St Katharine's Lodge, The Scores, St Andrews KY16 9AL, UK; jh105@st-andrews.ac.uk (J.H.); tcd@st-andrews.ac.uk (T.D.)

* Correspondence: elg5@st-andrews.ac.uk

Received: 29 August 2017; Accepted: 2 November 2017; Published: 9 November 2017

\begin{abstract}
Heritage sites are constantly changing due to natural processes, and this change can happen fastest at the coast. Much legislation has been enacted to protect sites of historic interest, but these do not protect sites from natural processes. Change is already happening, and climate change predictions suggest that the pace will accelerate in the future. Instead of seeing the potential destruction of heritage sites as a disaster, we should embrace the opportunity that they can provide for us to learn about the past and to plan for the future. Heritage laws often enshrine a policy of preservation in situ, meaning that our most spectacular sites are preserved in a state of equilibrium, with a default position of no permitted intervention. However, the options for threatened coastal sites mirror those of shoreline management plans, which usually recommend either the construction of a coastal defence or, more likely, a strategy of managed retreat, where erosion is allowed to take its course after appropriate mitigations strategies have been enacted. Managed retreat can lead to a range of research projects, some of which would not normally be possible at similar, unthreatened and legally protected monuments. Such research also has the potential to involve members of the public, who can help in the discovery process, and cascade what they have learned through their communities. Information shared can be about the heritage site itself, including how communities in the past coped at times of climatic stress; and also about the processes that are now threatening the monument, thus helping teach about present day climate change.
\end{abstract}

Keywords: archaeology; coast; erosion; climate change; community; heritage; environment; global change

\section{Introduction}

Climate change is an international issue which will impact global infrastructure and society. Manifesting in a variety of ways in different areas, it drives major environmental changes including higher temperatures, melting ice sheets, thawing permafrost, sea level rise and changing weather patterns. Coastlines are especially vulnerable and rising sea levels can lead to submergence, wave surges and coastal flooding. The possibility of more frequent and intense storms will generate powerful winds and waves, causing erosion and destroying land. The coastal zone is often of socio-economic importance, with population centres, industry, infrastructure and property located near the coast. The threat posed by erosion and flooding therefore has the potential to repeatedly place local populations in danger and cause extensive damage to a range of assets. Different areas will experience these effects in varying ways, with some low-lying, developing countries and small island states suffering the most severe impacts in the short term.

Climate change represents an additional challenge to buried and built heritage and will amplify the effects of natural processes and decay upon cultural heritage. In many countries across the globe, the coastal zone has historically been an area of importance, corresponding to focal points of human 
activity and leaving a rich legacy of sites. This means that many heritage sites are especially vulnerable to the impacts of climate-driven coastal change; and coastal erosion has been identified as the greatest natural agent of change facing the historic environment (Cassar 2005).

The importance of archaeological heritage is recognised at international level; the preamble of the European Convention on the Protection of Archaeological Heritage (the Valletta Convention) notes that it "is essential to a knowledge of the history of mankind" (Council of Europe 1992).

The Valletta Convention also recognises the vulnerability of heritage sites to a range of threats, both natural and anthropogenic. In this convention as in national guidance and policy, there is a presumption in favour of preservation in situ (Keers et al. 2011; Pickard 2001; Scottish Government 2014a). Although many human-derived threats can be managed and mitigated through legislation, with for example a responsibility for developers to ensure that a historic site is recorded prior to destruction by development (preservation by record) natural threats are more difficult to address.

Although this paper presents examples from Scotland, these challenges are being faced across the world. Scotland provides a good case study as it is a maritime nation, with a coastline over $18,670 \mathrm{~km}$ long (Angus et al. 2011) 21\% of which has been identified as 'soft' (CCC 2016a) and therefore vulnerable to coastal processes. Offering proximity to marine resources, access over water by boat and, in many locations, the best agricultural land, the coast has always been a preferred location for settlement, economic and industrial activity. This has left a rich legacy of archaeological sites concentrated in the coastal zone. Much of Scotland's coastal heritage is vulnerable to coastal process, and the impacts are expected to be exacerbated by climate change. Scotland is thus able to demonstrate the various ways in which environmental changes will impact coastlines and presents the breadth of heritage which may be at risk. Threatened heritage is therefore a useful proxy indicator for other assets at risk, especially on coastlines which are unprotected, leaving infrastructure, housing or other assets vulnerable to loss.

The following discussion explores the strategies that have been adopted at the Scottish coast and the collaborative approaches developed by communities in response to the threat to coastal heritage sites. In doing so, it demonstrates how partnership working at archaeological sites has contributed to archaeological knowledge, improved management of the threatened resource and generated wider public understanding of current environmental change and future challenges.

\subsection{Addressing the Threat at the Coast}

Coastal erosion is a complex, necessary and natural process. Sediment movement recycles material and replenishes beaches, maintaining coastal habitats and landscapes. Landward retreat is a response to sea level rise. By providing a soft buffer, many coastal environments such as salt marshes absorb wind and wave energy, acting as natural coastal defences (CCC 2016b, p. 102). Management policies therefore encourage minimal intervention to allow these processes of evolution (SNH 2000a).

Nevertheless, it is recognised that many assets are vulnerable to coastal processes. Shoreline Management Plans are one of the tools used by Local Authorities in Scotland to assess risk to assets in the coastal zone (Hansom et al. 2004). These present various options including defending the coastline to protect valuable assets; the determination of 'value' usually being economic.

In a handful of cases, coastal defences have been constructed for cultural heritage assets; usually iconic sites such as the Neolithic settlement at Skara Brae, a UNESCO-listed World Heritage Site, or St Andrews Castle and Cathedral (Dawson 2015). However, such defences are expensive to build and maintain and, by disrupting the natural system, can cause or exacerbate damage in adjacent areas, so are only rarely constructed for heritage value. As a consequence, many archaeological sites remain vulnerable to the impact of erosion.

Given time and the space to do so natural habitats can migrate landwards under the pressures of erosion; birds and animals can move, plants can recolonise areas, and coastal landscapes can recover and repair themselves (SNH 2000b). However, archaeological sites are a static, irreplaceable, 'finite and non-renewable resource' (Department of the Environment 1990), and so damage or loss is 
irreversible. It is up to us to find ways of responding to the threats posed by coastal change upon our archaeological resource.

\subsection{Understanding the Threats to Scotland's Coastal Heritage}

In Scotland, Historic Environment Scotland (and its predecessor Historic Scotland) has taken the strategic lead in gathering evidence on the specific threat to archaeological sites from coastal processes (Ashmore 1994), including the establishment of the SCAPE Trust (Scottish Coastal Archaeology and the Problem of Erosion) in 2000. SCAPE is a charity set up to research and promote the archaeology of Scotland's coast and a central tenet of its philosophy from the outset was the involvement of the public. Public involvement is key to addressing these issues; not only is it in line with the principles of sustainable development, but as highlighted by Dawson et al. (2017) awareness and participation are central to facing such challenges. Principles of community involvement are also emphasised in the sector's strategy for the Historic Environment Our Place in Time (Scottish Government 2014b) and Scotland's Archaeology Strategy (Historic Environment Scotland 2014).

Since 1996, Historic Environment Scotland has commissioned a series of Coastal Zone Assessment Surveys (CZA Surveys). These gathered baseline data and quantified both the archaeological resource of Scotland's coastal zone and the threat it faces from natural processes. These surveys were managed by SCAPE from 2000 and to date 29 individual surveys have covered c. $35 \%$ of the Scottish coastline (Figure 1). Areas selected for survey were those deemed to be most vulnerable to erosion and coastal processes. In accordance with guidelines created by Historic Scotland (1996) and updated by SCAPE (Dawson 2008) the CZA Surveys recorded all archaeological sites as well as the geology, geomorphology and erosion class of the coast. This programme of work aimed to develop regional and national priorities and inform decisions about the future management of the resource (Historic Scotland 1996, pp. 2-4). Thus, the surveyors also made an assessment of sites' vulnerability to erosion and provided recommendations for further work where considered necessary. Over 12,000 archaeological sites were recorded, with further work recommended at nearly one third of these (Dawson 2010, p. 3).

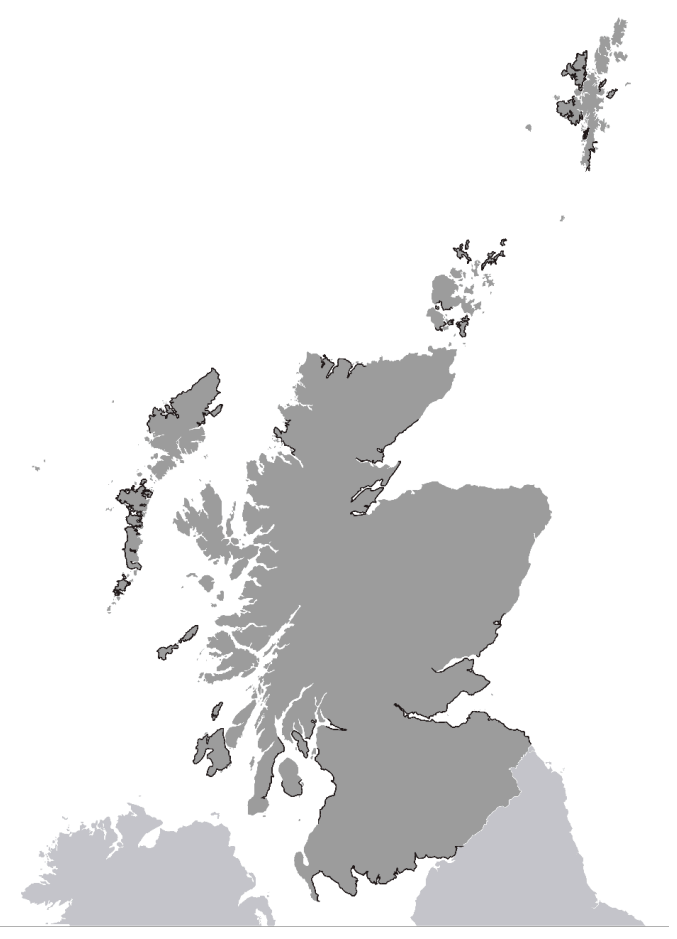

Figure 1. Map of Scotland showing the $35 \%$ of the coast which has been covered by CZA Surveys. 


\section{Analysis and Prioritisation}

The vast number of sites which were judged to require additional work far outstripped resources available. In order to develop this CZA Survey dataset into a management tool for the coastal archaeological resource, an analysis was undertaken by SCAPE, in partnership with Historic Environment Scotland and local authority archaeologists in 2010 (Dawson). Using national designation criteria, to assess the archaeological value of sites, and a GIS approach to assess the level of threat they faced, it was possible to extract the most important and most vulnerable sites for prioritising future action. By standardising site records across the different surveys, this examination brought parity and consistency to the CZA Survey data. This established a national perspective and transformed the data into an evidence base from which to develop policies and inform strategies for addressing the issue of coastal heritage loss. The prioritised site list highlighted 940 sites as most vulnerable to loss from coastal processes, with recommendations for action at each of these high-priority sites. The work also highlighted the change which may have taken place at many sites since they were first recorded, in some cases up to 20 years earlier. In order to investigate these changes systematically, the first action recommended for the prioritised sites was a site visit and up to date assessment of their current condition.

\subsection{Scotland's Coastal Heritage at Risk Project}

SCAPE's ethos of recognising the value that communities can bring to the management of Scotland's coastal archaeological resource, led to the development of the Scotland's Coastal Heritage at Risk Project (SCHARP, www.scharp.co.uk (SCAPE Trust 2012)), launched in 2012. Building upon SCAPE's previous community projects at threatened sites, SCHARP took the prioritised CZA Survey data one step further and addressed the need for updated records of the condition of high-priority coastal sites. In doing so, it aimed to create partnerships between local communities and heritage professionals.

SCHARP has two main elements. In ShoreUPDATE, volunteers from local communities around Scotland were trained and supported to carry out site visits to update and improve information about priority sites, while ShoreDIG integrated community value into the selection of sites for work by undertaking practical projects at high-priority sites nominated by the local community (Dawson et al. 2017).

\subsection{ShoreUPDATE}

To facilitate the collection of survey data, an interactive, web-based map portal (www.scharp. co.uk/sites-at-risk) was developed. All 12,000 CZA Survey sites were made accessible by clicking markers which were colour-coded according to their assigned priority status. The same information was made available through a mobile app. Through these interactive portals, volunteers can use the ShoreUPDATE survey form to update information about a site's condition and submit photographs. The creation of the mobile app democratised participation, by allowing volunteers to use their own, familiar devices, with built in GPS and camera, to carry out surveys. The survey form was designed to standardise information collected, with simple questions and multiple-choice answers focused on recording condition information. Several additional questions addressed the project's interest in collecting local knowledge and recording a site's value as perceived by the community. The collection of photographs was a key part of the survey; they enhanced the data, were used to compare with previous surveys, and acted as a baseline against which to judge future change.

Training events for communities were held around Scotland. These not only introduced volunteers to the technology and offered practical guidance in carrying out archaeological surveys, but also stimulated local interest in the project, encouraged participation from new audiences, developed volunteers' confidence, and built relationships between the project team and the community of 
volunteers. All records submitted to the project were moderated by project officers prior to being published on the website and shared with regional and national heritage databases.

Although all 12,000 records of coastal sites were made available through the website and app, the specific focus of ShoreUPDATE was the 329 sites identified as highest priority by the CZA Survey analysis (Dawson 2010). In 2017, following four years of data collection, SCAPE undertook a review of the updated records generated by volunteer surveyors (Hambly 2017a). This review of ShoreUPDATE data highlighted the dynamic nature of the coastline; in some areas there was evidence of stabilisation since the original survey, but elsewhere, many vulnerable sites continue to deteriorate. In some cases, sites had been destroyed by erosion since they were first recorded with the loss of valuable knowledge about the past, while for some sites the impact of erosion has been mitigated by archaeological intervention to rescue information (e.g., Garrow and Sturt 2017). The ShoreUPDATE process also recorded a number of vulnerable sites newly-exposed by erosion, while other sites which had not originally been deemed vulnerable were now judged to be under urgent threat of loss. This varied picture emphasises the degree of change in the dynamic coastal zone, and the need for continuous monitoring, in which there is a key role for local communities.

Following consultation with stakeholders, this reviewed dataset now constitutes a refined list of priority sites for action based on the urgency of threat at important sites, based on observations made during the activity period of SCHARP (Hambly 2017a). Thus, the project has created a tool for improved management of the vulnerable coastal archaeological resource by heritage managers and local communities. The data is applicable far more widely, to natural heritage specialists, geologists and geomorphologists, as well as a range of other disciplines, such as climate scientists, planners and policy-makers. ShoreUPDATE surveys have provided well-described, observational data gathered within the defined, relatively short timescale of the project. Although the focus was on recording the condition and vulnerability of archaeological sites, the surveys also examined the condition of the coastline and the wider landscape and provided a photographic record of eroding coastlines from places around the entire coast. Updating the original CZA Surveys has thus provided a dataset of spot-checks on the coast, creating a network of vulnerable sites where the impacts of climate driven coastal change can be measured and forming a robust baseline for ongoing monitoring.

The model of community participation is well-suited to addressing the problem of archaeological sites under threat within the dynamic coastal zone and the call for volunteer ShoreUPDATE surveyors met with a strong response, with over 1000 volunteers participating in SCHARP (Hambly 2017b). This strong response from local communities reflects their awareness of the need for work to address the issue of coastal archaeological sites under threat. Another significant result of the project has been the creation of a network of coastal heritage stewards in local communities. Local volunteers are well-placed to maintain a presence to monitor future climate impacts on the coast and archaeological sites by making repeat visits in different conditions such as during extreme low tides, in winter months when vegetation levels are low, or following storm events to check for change or damage. Public involvement also raises the value of heritage, and the project has engendered a collective sense of ownership of this vulnerable heritage.

The focus on sites vulnerable to coastal processes has also raised awareness within the community of climate change and other threats to heritage. Scotland's heritage is highly-valued internationally, and is a central part of the country's national identity; but value also operates very strongly, arguably most intensely, on a local level (Jowell 2005, p. 12). By observing and recording the impacts of climate change-exacerbated coastal processes on locally-valued sites, volunteers have gained a stronger understanding and appreciation of the threat they pose. Repeat visits to monitor condition can reveal ongoing change, enhancing appreciation of the broader issues and challenges.

\subsection{ShoreDIGs}

Previous projects which worked on threatened coastal heritage found that groups who were engaged with their coastal heritage and undertook monitoring work at sites could become disillusioned if a site 
they had been observing was lost to erosion (Dawson 2015). As noted by Fraser et al. (2003, pp. 201-2), fostering a sense of stewardship engenders a drive for further work at threatened sites.

The second part of SCHARP, therefore, aimed to go beyond recording sites by undertaking practical projects at locally valued yet threatened sites. A total of 14 ShoreDIG projects were carried out around Scotland (Hambly 2017b).

The sites selected span all periods and represent the breadth of human activities carried out at the coast. This variety also showcases the different strategies adopted at each ShoreDIG, from traditional archaeological survey and excavation, to interpretation, film-making, and 3D digital documentation. Despite the diversity of sites and approaches, the ShoreDIG projects have several common elements. All were undertaken at sites with intrinsic archaeological value, under threat from coastal process and valued by the local community, and a central element of each was opportunities for training and involvement for local volunteers. Not only have these projects saved information that would otherwise be lost, and enhanced knowledge about the historic environment, they have evaluated techniques for carrying out work in challenging environments and provided examples of possible actions at sites threatened by natural processes. Moreover, as collaborative projects bringing together heritage and other professionals working in partnership with local groups, they have also been mechanisms by which coastal communities can engage not only with their heritage but with the impact of coastal change within this fragile environment. The following case studies (Figure 2) present examples of different projects which have integrated community action and archaeological research at locally valued coastal heritage to explore the issue of coastal change and mitigate its impact.

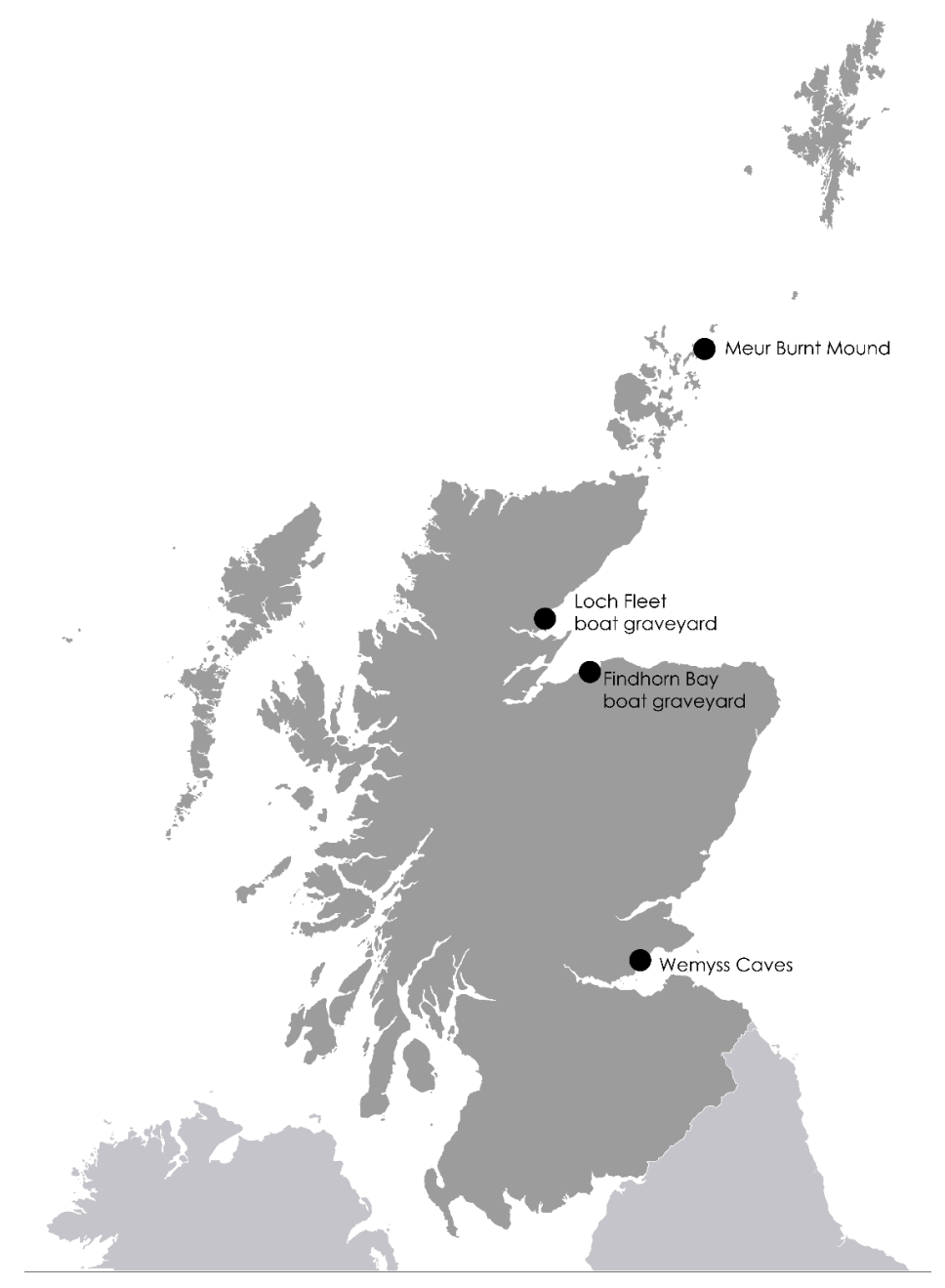

Figure 2. Map showing locations of ShoreDIG case studies. 


\section{Case Study: Boat Graveyards}

In the 19th century, the herring fishery was of huge economic significance in Scotland. Thanks largely to the introduction of Government subsidies on larger boats and bounties on the overseas sales of herring, the Scottish fishing industry became the largest in Europe. The fishing industry in Scotland has been well-studied, with a rich resource of data available in the Annual Reports of the Fishery Board for Scotland and photographic collections which provide contemporary images. However, very little survives of the fleet itself which at its height numbered over 10,000 vessels.

While undertaking a ShoreUPDATE survey, a group of volunteers from the North of Scotland Archaeological Society (NOSAS) recorded the remains of a collection of wooden boats on the sheltered south shore of Loch Fleet in East Sutherland, Highland region. The remains comprise the wooden elements of the lowest part of the boats' hulls. Partially buried by beach sediment; the keels, collapsed fragments of wooden hull structures and occasional other timbers standing to around $1 \mathrm{~m}$ in height are visible. Located in the intertidal zone, the remains are badly deteriorated, vulnerable to erosion on the beach, and inundated by tides daily. In the face of rising sea levels and increasing sea temperatures, these fragile remains are also under increasing threat from boring organisms such as a range of shipworm species (Graham et al. forthcoming). The only previous record of the site was based on a 1995 article in the local newspaper the Northern Times which suggested that the vessels were the remains of the herring fishing fleet of the local village of Embo which had been deliberately scuttled and burned at the end of the First World War due to the migration of the herring and the loss of life in the conflict.

Despite their poor condition, the remains acted as a catalyst for research, when the local group recognised the interest of the site. They nominated it for further investigation as a ShoreDIG project (Graham and Hambly 2017a) which has helped us understand the relationship between humans, fishing and the exploitation of the sea's resources. In collaboration with members of the local community, a project was developed to record the remains and research their history. An archaeological survey was carried out by SCAPE, NOSAS, the Nautical Archaeology Society (NAS) and local volunteers, which created a record of the remains and their condition (Figure 3). Research was carried out within the local community, including a search of archives, the collection of oral history and the identification of a number of historic photographs of Loch Fleet showing vessels hauled out on the shore. Oral histories collected in the local fishing community of Golspie in East Sutherland (Dorian 1985) indicated that the fleets of both Golspie and Embo routinely used Loch Fleet as a safe haven in bad weather and in winter outside of the herring season; the former on the north shore, the latter to the south, both to avoid harbour fees and because of the dearth of suitable local harbour facilities. The importance of the sheltered loch for the Embo fishermen particularly was intensified by the inadequate pier at the village. The pier was constructed in $1895 / 6$ and was notoriously difficult to access until local demand compelled refurbishment in 1934 (A Coombs pers. comm.).

A little after the first survey, a NOSAS member identified a second similar boat graveyard on the west shore of Findhorn Bay in Moray, and the site was suggested as a second, complimentary ShoreDIG project (Graham and Hambly 2017b). The site comprised a similar group of remains; and a similar methodology combining survey and research was employed.

Like the fishermen of Embo, the crews of the Moray coast boats appear to have used informal safe havens at times of bad weather and outside of the season. The natural harbour of Findhorn Bay was praised in the mid-19th century New Statistical Account (Gordon 1999, vol. 13, p. 211) and reports in local newspapers following a storm in early 1914 (Forres Gazette, 18 February 1914) recorded that the Binsness shore of Findhorn Bay was a customary winter shelter for the herring boats. A photograph of 1908 further attests to this, showing ranks of large sailing boats hauled out on the west side of Findhorn Bay, opposite the village.

Examination of the physical remains of the boats at both sites confirmed that most of the vessels had been First Class Zulus. These distinctive sailing drifters were developed in Scotland in 1879 during the Zulu wars and were named to honour the Zulu warriors. Noted for their speed 
and manoeuvrability, they came to dominate the east coast herring fleet in the late 19th century (Tanner 2010, pp. 15-16). Despite their pre-eminence in the herring fishery, however, very little now remains of "the Mighty Zulu" (Reid 2012) with only four now recorded on the UK's Register of Historic Vessels (National Historic Ships UK 2017).

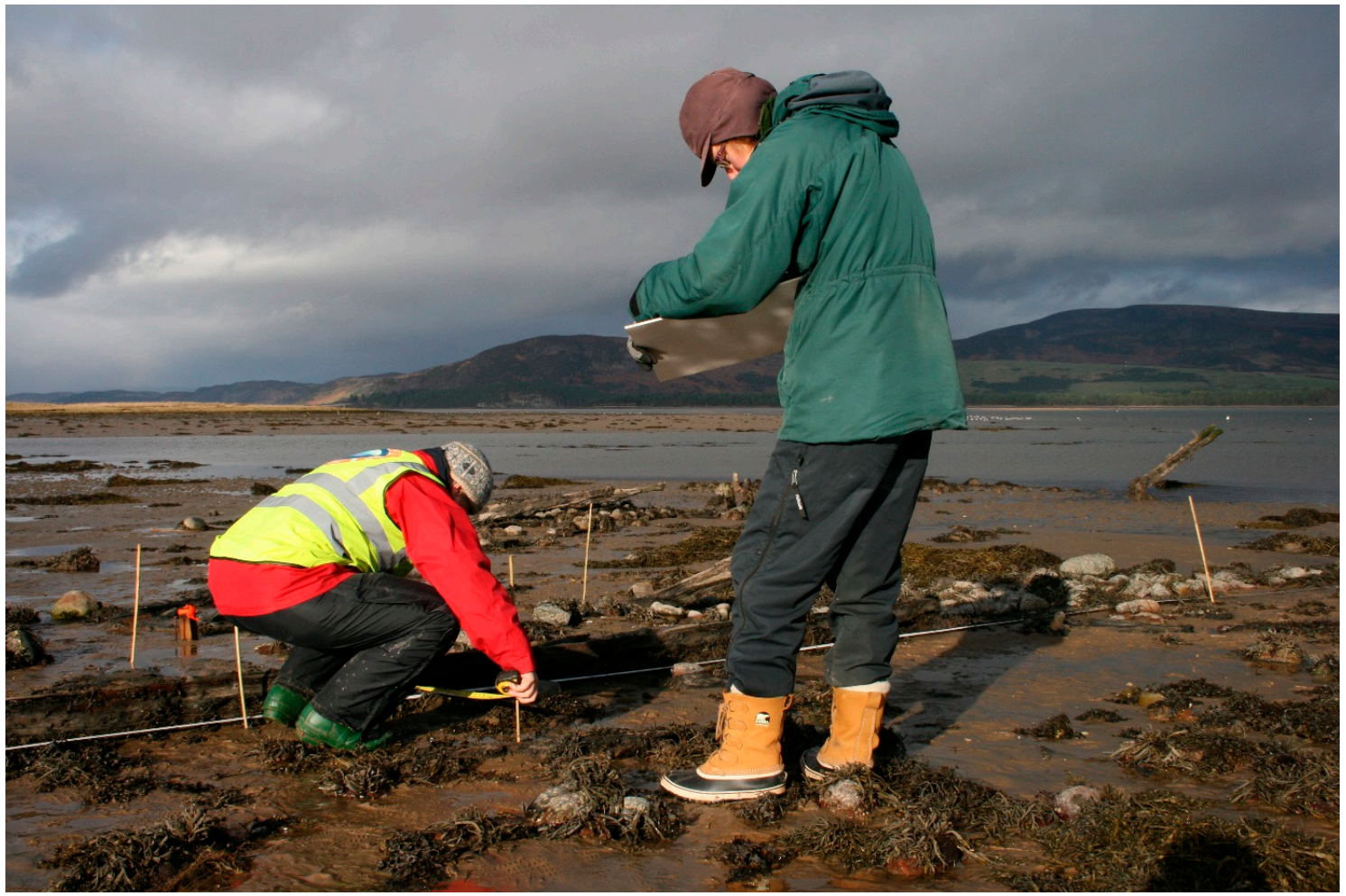

Figure 3. Volunteers recording the remains of a boat, Loch Fleet, February 2014.

The Annual Reports of the Fishery Board for Scotland contain a wealth of information about the state of the herring fishery, recording catches, numbers of boats and employment figures supported by the industry. These show that the national fishery was enjoying steady growth in the first decade of the 20th century (Graham and Hambly 2017b). Conversely, in East Sutherland, the herring fishery in the village of Embo and the wider district of Helmsdale collapsed during this period, and had already essentially ceased by the First World War (Graham and Hambly 2017a). Likewise, in Findhorn, the data reflects a change in the composition of the herring fleet; although the number of resident fishermen is maintained over the same period, the number of smaller herring boats fell sharply, and the production and export of the Moray coast districts steeply declined. The national picture appears to mask a more complex variation at local and regional level.

The fishing communities of the east coast of Scotland experienced the same wholesale change in the early 20th century as society across the rest of the country, and these changes can be examined through the lens of their impact on the local fisheries. A central factor was the introduction of steam power to the fishing fleets. Over the decade prior to the outbreak of the First World War, steam vessels came to dominate the herring catch (Sutherland 2015) and competing with this was beyond the reach of sail. Retrofitting boilers to older wooden Zulus was neither economically viable nor feasible. A wholesale move from sail power to steam is demonstrated by the records of the Moray boatyards in the mid-1900s (Crawford et al. 2010, pp. 204-5), and sailing drifters were rendered obsolete. Steam drifters were significantly larger than the old First Class sailing vessels, and could not be accommodated in small village harbours. Furthermore, they were correspondingly more expensive, prompting a change in the ownership patterns away from the old model of shares held by the crew. 
Instead, fishermen began hiring their labour out to larger, non-local boats (Dorian 1985, p. 58). As the local fisheries declined, the industry became concentrated in fewer, larger port towns; although a general decline was reflected in the fishing communities as employment was sought elsewhere, and a 'shore job' was perceived as a measure of success (Dorian 1985, p. 31).

As they lost their value, a glut of second hand sailing vessels is attested by the numbers offered for sale in local newspapers (Banff Advertiser April 1909; December 1909) and much of the fleet was ultimately abandoned on shores which had been long established as winter havens for out-of-season storage (Graham and Hambly 2017a, 2017b). Photographs shared by the Findhorn community show a family playing on this shore (Figure 4). Securely dated to summer 1913 by positive identification of the children, these confirm that these wooden sailing boats had not joined the herring fishery that year.

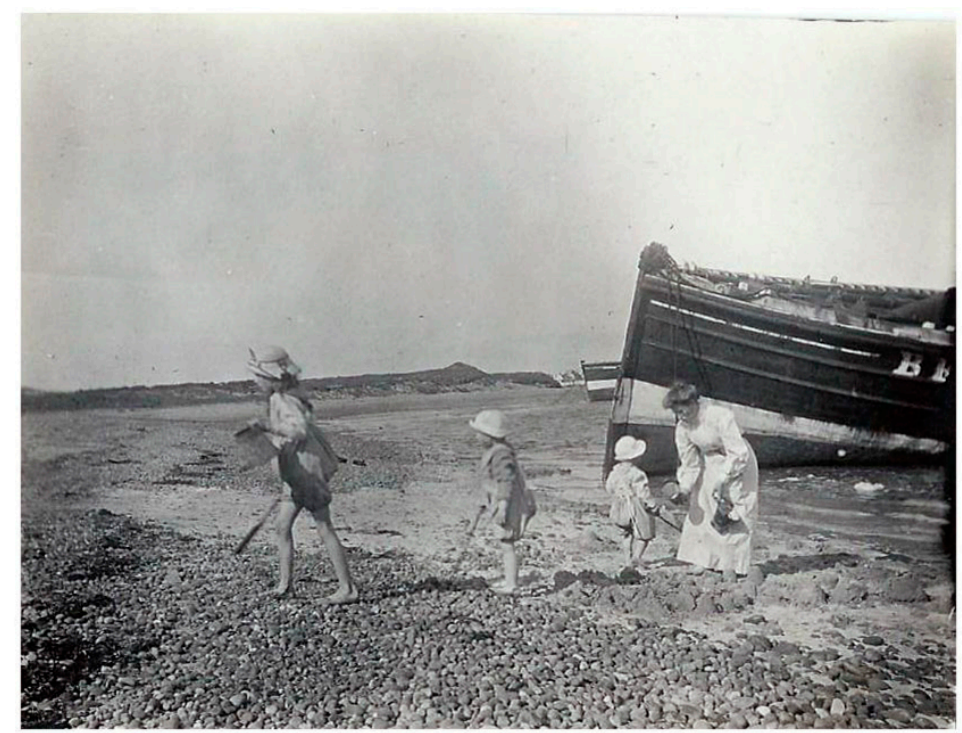

Figure 4. Findhorn Bay August 1913, showing herring boats hauled out on the shore. Photo from Forres Heritage/Henrietta Grant-Peterkin.

Thus, the loss of the local fleets mistakenly linked to the dramatic watershed of the First World War in fact largely pre-dated the conflict and forms part of a more nuanced story of longer-term change and adaptation in the face of the emergence of new technology and significant socio-economic reorganisation.

The two ShoreDIG projects corrected the story of a deliberate burning event and the false attribution of the loss to the global crisis of the Great War, as well as creating new records of rare and vulnerable heritage. These previously unrecorded remains are the near-unique surviving physical manifestations of the national herring fishery and an important aspect of Scotland's history.

As well as documenting this fast-disappearing heritage, the projects provided opportunities for modern coastal communities to reflect on the history of their areas. Many coastal settlements in northern Scotland were specially constructed commercial fishing villages, established as a cornerstone of the Sutherland Estate's clearance policy (Tindley 2010), and most volunteers involved in the ShoreDIG projects either lived in or had connections with these villages. Through participation in the surveys, local volunteers could examine how past communities, which had existed for-and been dominated by - the herring fishery, adapted in the face of change. The collaborative research revealed a complex picture of community resilience when faced with major socio-economic transformation in a changing world which rendered their way of life redundant. 


\section{Case Study: Meur Burnt Mound}

Burnt mounds are found across northern Britain, Ireland and Scandinavia, but despite their prevalence, their function remains obscure. Manifesting most frequently as piles of burnt stone, in association with a source of fresh water, and a tank or trough into which the heated stones appear to have been plunged, they are predominantly dated to the Bronze Age (Doughton 2014). A paucity of finds or other diagnostic evidence from such sites has exacerbated difficulties of interpreting their purpose, and theories as to their use range from a variety of industrial processes to cooking, feasting, bathing or prehistoric saunas. A handful of burnt mounds in the northern isles of Scotland, known as complex burnt mounds, are associated with stone structures (Hedges 1975; Moore and Wilson 1999, 2001, 2008, 2014).

A further site was added to this small group when structures, initially thought to be the remains of a cist burial, were revealed by a winter storm in 2005 on a beach at Meur, on Sanday, one of the islands of the Orcadian archipelago. Rapid archaeological excavation following the exposure (Toolis 2009) identified the remains as a complex burnt mound. The damage inflicted by regular winter storms in subsequent years to the partially excavated site provoked an aspiration in the local community to rescue the site. Inspired by a previous SCAPE project at another complex burnt mound in Cruester, Shetland (Moore and Wilson 2008) and galvanised by the launch of SCHARP, the island's community formed the Sanday Archaeology Group and nominated Meur Burnt Mound as a ShoreDIG. With the creation of a new Heritage Centre for the island acting as a further catalyst, the proposed project was developed by the group in partnership with SCAPE and aimed to relocate the burnt mound structures to the museum as a visitor attraction. Although relocation of sites is controversial, this situation exemplified the stark choice between total loss or archaeological excavation and recording (preservation by record) followed by rebuilding elsewhere.

In order to allow the structures to be dismantled and moved, the first step was the re-excavation of the site (Figure 5). The features recorded by the original excavation included small cells constructed of large upright flagstones, a stone-lined tank, a paved passageway and a corbelled structure interpreted as a water cistern (Toolis 2009). Comparison with excavated examples of other complex burnt mounds (Moore and Wilson 1999, 2001, 2008) had allowed the archaeologists to infer the existence of further structures, principally a hearth cell in which stones were burned prior to being added to water in the stone tank. Erosion in the interim had made more of the site accessible and allowed fuller investigation of features during the ShoreDIG project, including the corbelled structure, which was found to be a prehistoric well nearly $3 \mathrm{~m}$ deep (Dawson 2015). Furthermore, as the work progressed, the dismantling of the structures for relocation exposed an unsuspected earlier phase of the monument. Beneath the slab which formed the base of the tank, further stonework was revealed, which investigation showed was part of a Neolithic well. In both well features, waterlogged deposits contained well-preserved organic material, such as seeds, beetles, and plant fragments (Dawson 2015). Analysis of these remains will allow detailed reconstruction of the local environment and climate of prehistoric Orkney around 5000 and 3000 years ago.

A key element of the project, as with all ShoreDIGs, was the involvement of the local community. The value placed on the site was reflected in the levels of engagement in the project. Not only was much of the archaeological fieldwork carried out by volunteers from Sanday, but participation by the community was a central element of the relocation of the monument. Local farmers contributed the use of their equipment and time to dismantle the site and transport the stones across the island for reconstruction. Where elements could not be removed from site without exacerbating the damage caused by erosion, replicas were built. This provided an opportunity for the professional stonemasons building the reconstruction to deliver training to the local community in traditional dry-stone building techniques. Additionally, a local artist created an illustration of the burnt mound in use for the on-site interpretation board.

This project has added significantly to archaeological knowledge of burnt mounds. Furthermore, the waterlogged organic material recovered presents a unique resource of enormous research potential for informing understanding of the prehistoric environment of Sanday and past environmental change, 
as well as the practices associated with burnt mounds. The investigation of a monument which was exposed on a beach is thus contributing to knowledge of past coastal and sea level changes.

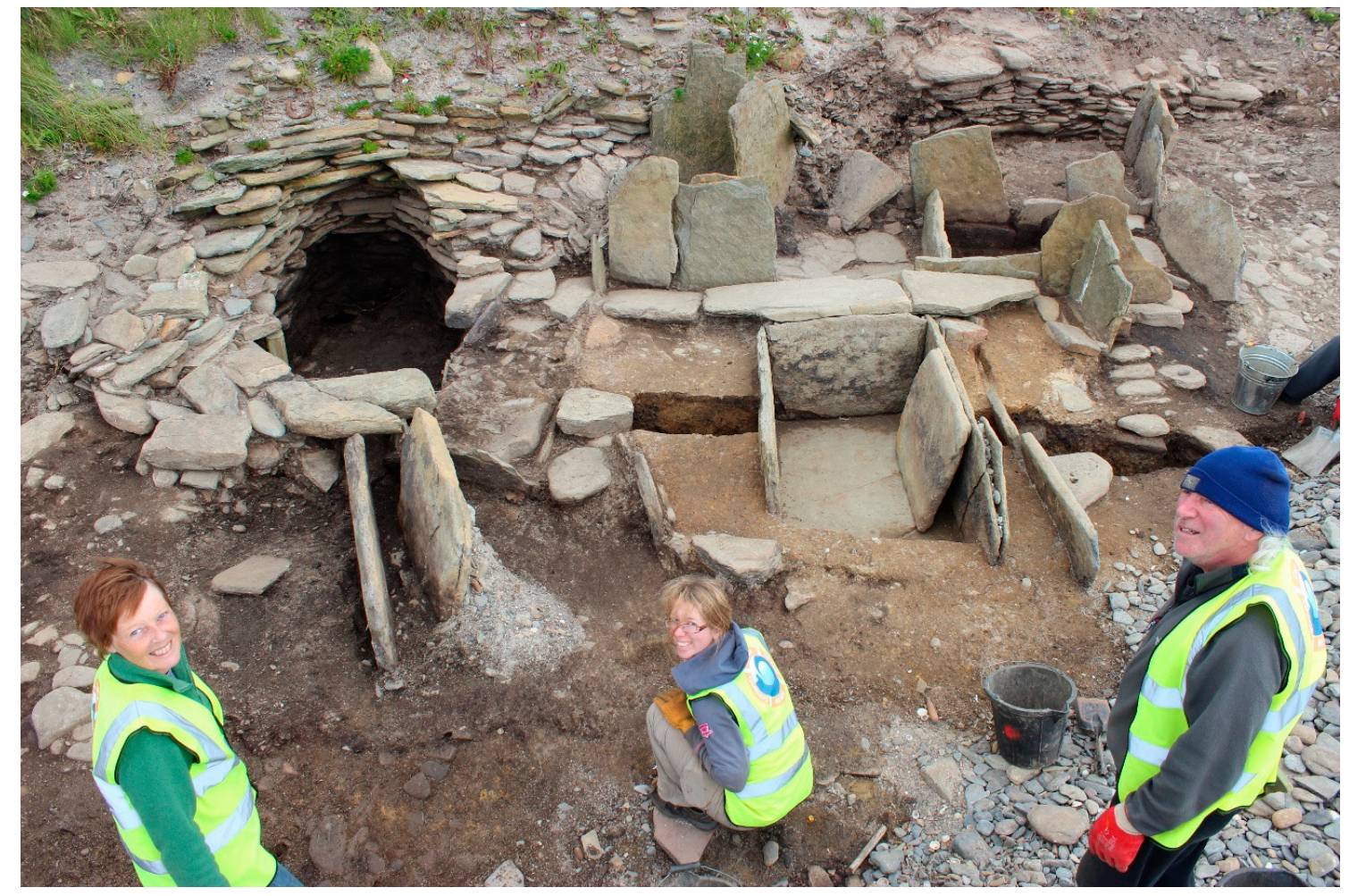

Figure 5. Some of the team on site during the excavation of the burnt mound of the beach at Meur, July 2014.

This wealth of important information was rescued from the sea thanks to the community's aspirations to save a site which was perceived by heritage professionals as having been archaeologically examined (Dawson et al. 2017). Although erosion was destroying the site, it also presented an opportunity to investigate a monument more fully than would otherwise have been possible. By working at a site threatened by current coastal change, the project has rescued information from which we can learn about past environments. However, the ShoreDIG also created a tangible legacy for the island in the form of the reconstructed monument. This now forms an attraction for visitors, while the associated on-site interpretation and display in the adjacent museum discuss burnt mounds and the prehistoric landscape of the island (Figure 6). The displays also consider the issues of the island's spectacular eroding archaeological heritage; Sanday's coast is both very vulnerable to erosion and contains a number of world-class sites. By examining this threatened heritage, the museum explores the modern processes which are damaging the sites and the island's coastline. Thus the archaeological work is used as a vehicle to bring to a wider audience the broader issues of erosion, the vulnerability of the landscape to the impacts of climate change and the challenges posed by environmental change at the coast. 


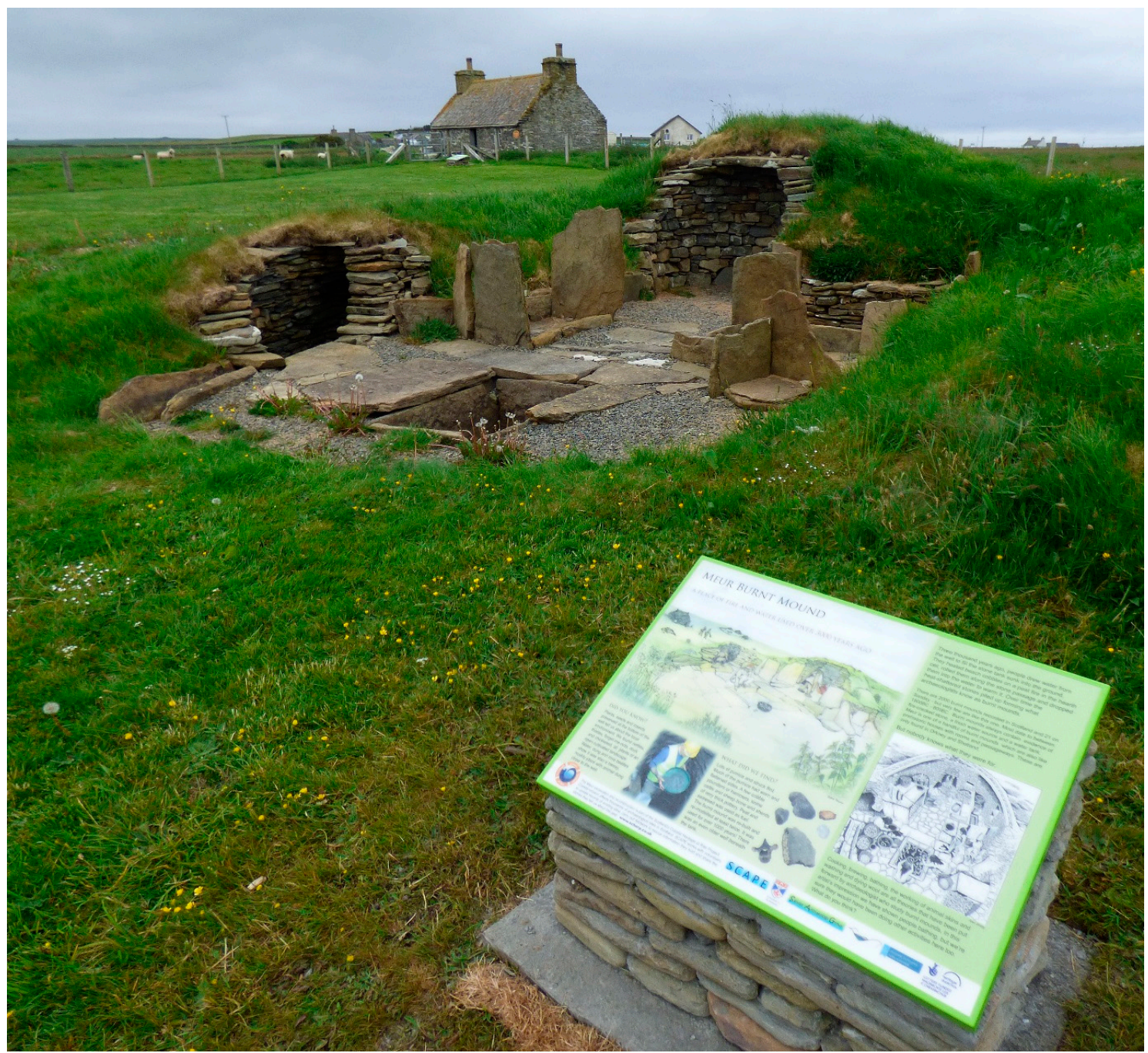

Figure 6. The reconstructed burnt mound structures and interpretation panel at the Sanday Heritage Centre.

\section{Case Study: Wemyss Caves}

The Wemyss Caves on the east coast of Fife are relict sea caves carved into the soft sandstone bedrock. Overlooking the Firth of Forth, they contain a rich collection of carvings, predominantly Pictish, though some may be prehistoric or Viking in date (Le Bon 1992); others are early Christian, while one cave contains a wealth of more recent carvings related to 19th century use of the cave and its holy well as part of New Year celebrations (Hambly et al. forthcoming).

The coastline, however, is threatened by the natural processes of erosion and slope failure, and $30 \mathrm{~m}$ of the coast have been lost since 1970 (National Coastal Change Assessment 2016). Erosion has been exacerbated by the history of coal extraction in the area. The mining industry led to the dumping of thousands of tons of colliery waste in the sea, which acted as a sediment source that replenished beaches and led to the coast edge extending out to sea. This land was then used, with a gasworks built to the east of the caves. Since the industry's demise in the 1980s, this sediment resource has been lost and the sea has started to reclaim the coast edge, leading to schemes of coastal defence which aimed to protect buildings and gas and water pipes. These protection works have failed (Figure 7), and the beach is littered with collapsed coastal defences, themselves an archaeological record of what can happen when defences aren't maintained. The collapse of the mining industry has also left a legacy of economic deprivation. This is manifested at the caves as anti-social behaviour 
and vandalism, culminating in an incident when a car was driven into one of the caves and set alight, destroying several carvings. The Save the Wemyss Ancient Caves Society (SWACS) was formed in response to these issues and since 1987 has worked to raise awareness of the significance of the caves.

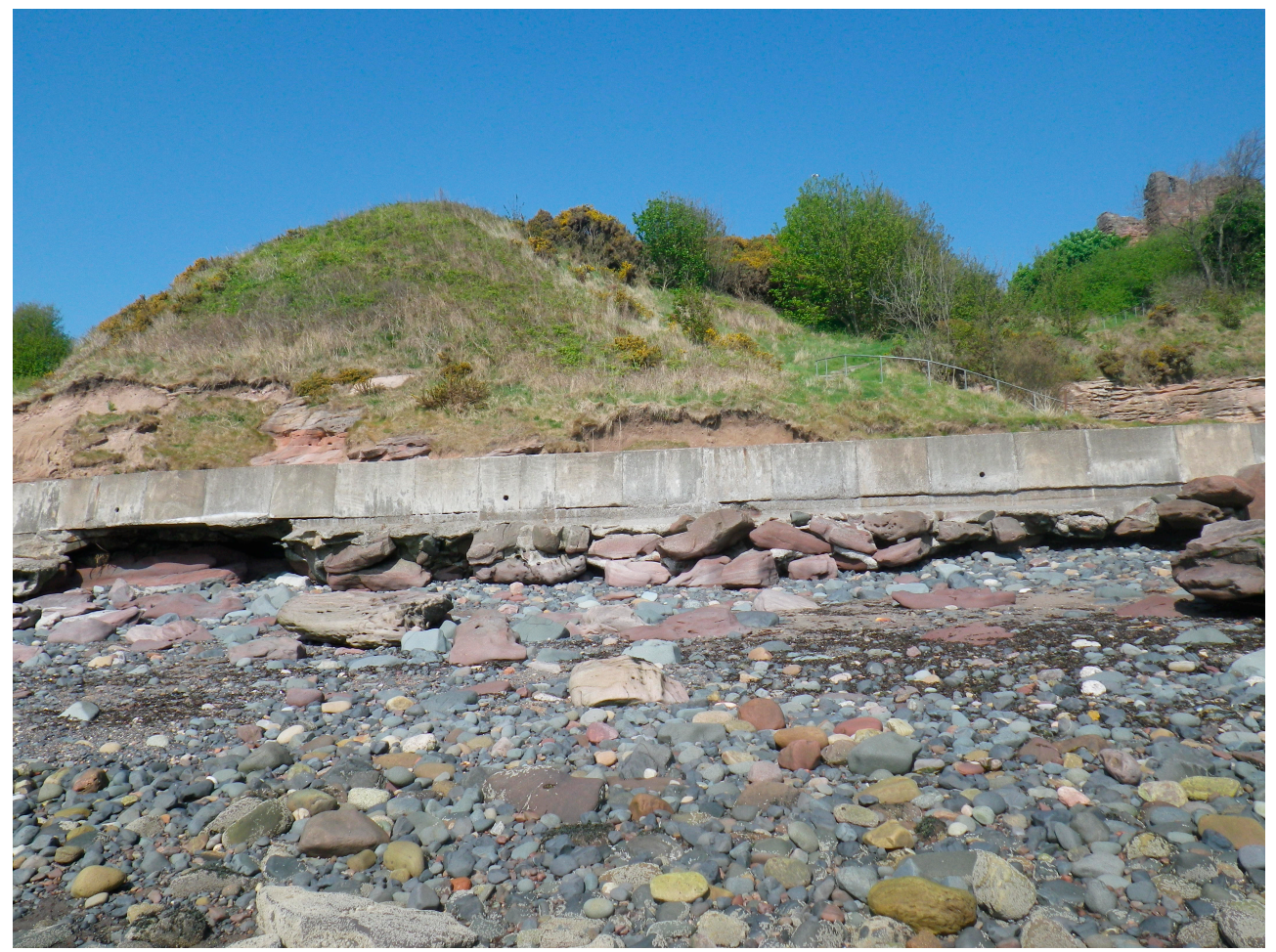

Figure 7. Failed coastal defence at Wemyss caves.

The ShoreDIG project at the Wemyss Caves was developed in collaboration with SWACS to contribute to these aims and the strategy adopted involved digital documentation and recording. Carried out in partnership with the York Archaeological Trust, the work deployed a range of techniques, including low-level aerial photography; laser scanning of the caves and the entire stretch of coast on which they lie, and various photographic techniques, including Structure from Motion and Reflectance Transformation Imaging (RTI) (Dawson 2015; Hambly et al. forthcoming). The latter technique is extremely well-suited to the caves' environment and to recording the carvings. By capturing a series of photographs by a camera in a fixed position with a moving light source, this method creates a digital image which allows the user to manipulate the lighting by shining a virtual torch to examine a surface and highlight details. Additionally, and in keeping with the collaborative spirit of ShoreDIG projects, local volunteers could carry out the fieldwork and use the freely-available processing software to generate interactive images. Skills embedded in the local community were also central to the archival research carried out as part of the project, which ultimately identified lost antiquarian records and rubbings of the carvings, located in the British Library, London.

This work has created very precise digital models of the landscape, the caves and the carvings, forming a management tool for the site and a highly-detailed record of the heritage and of the coastline (Hambly et al. forthcoming). In accordance with SWACS' ethos of celebrating the caves and raising perceptions of their value, the 4 dwemysscaves.org website is bringing the Wemyss Caves and their heritage to a global audience. The survey data formed a baseline from which the eroding coast was reconstructed, and presented on an interactive time slider allowing visitors to examine the landscape at various points through history to understand past coastal change. The data was also used to digitally recreate the caves, within which users can explore the carvings and access historic records about them. 
Antiquarian documentation of caves which subsequently collapsed has been used to digitally re-create lost caves and carvings.

This content is augmented by a series of short films, made in partnership with —and starring — members of SWACS, which showcase different aspects of the caves' history. Historic images of the areas were shared by the local community, further illustrating the dramatic change this coastline has undergone. Oral history interviews with the community recorded personal memories of the caves (Figure 8) and added an additional layer of information about more recent uses of the caves, such as a miners' illicit gambling game conducted in the caves out of sight of the law.

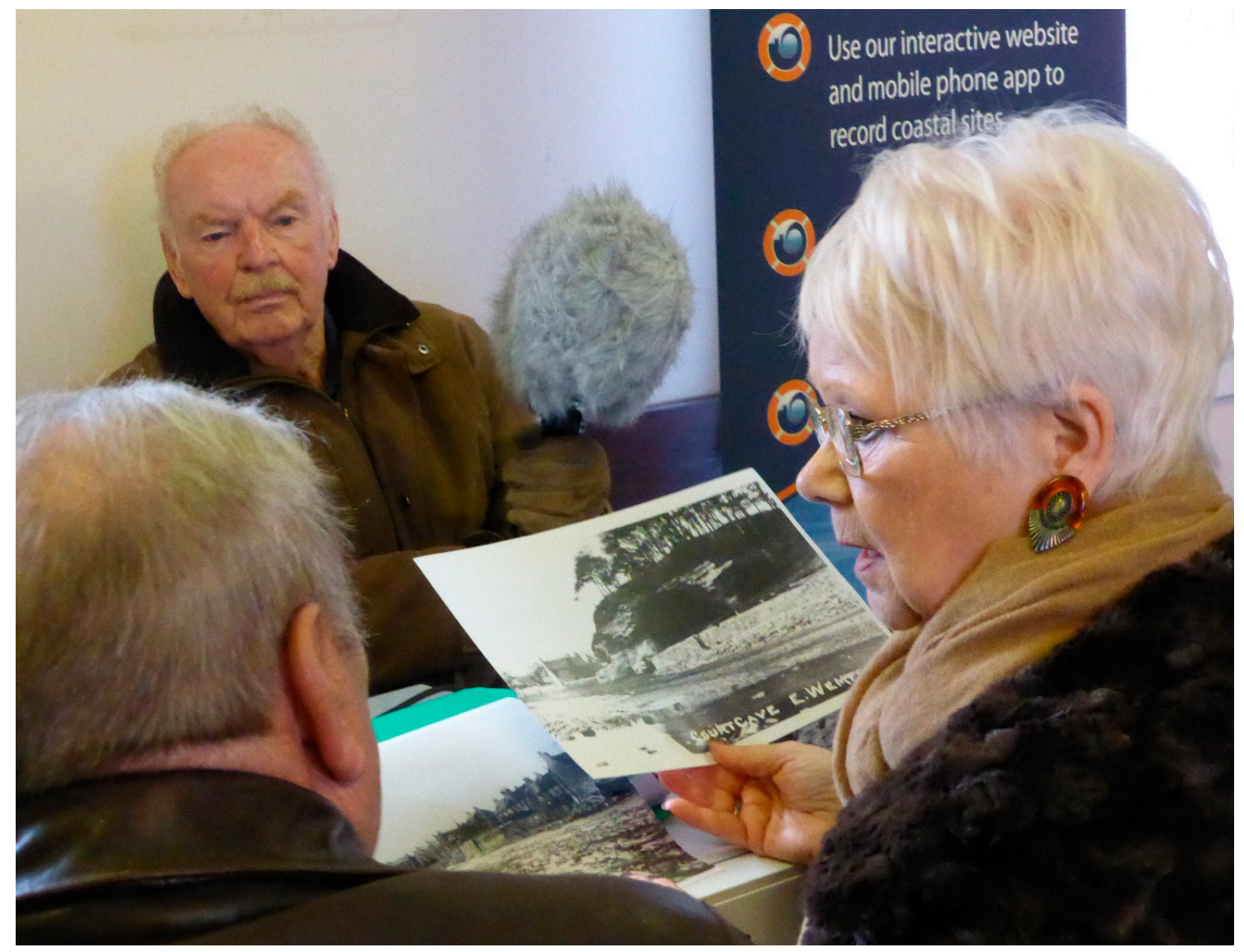

Figure 8. Interviewing the local community and collecting memories of the Wemyss Caves.

Alongside the digital resource created, the local community continues to care for the caves and their environment by; keeping the area tidy, running a small museum showcasing the heritage, holding open days for the public and offering guided tours, and arranging visits from local schools.

The twin aims of the Wemyss Caves ShoreDIG project, to record the unique heritage of the caves and celebrate their importance, are irrevocably entwined. The local community was involved at all levels of the project, from the design stage onwards - and have played a key role in generating the outputs. They have employed and developed a range of skills, including traditional archival research and applied digital documentation techniques, thus developing creative responses to the site. The breadth of methods employed has broadened involvement and widened participation beyond traditional archaeological audiences. The project has created a diverse output, communicating the value of the heritage in new ways to further increase its reach. A significant legacy of the project is the new skills embedded in the community and now being applied to other heritage; whilst the creation of the digital resource and its availability online, together with on-going improved management of the site, are further long-term benefits. Improved awareness of the site brings with it an increase in its 
perceived value, one of the key aims of the ShoreDIG project; and local, national and international audiences have been engaged through a variety of diverse outputs. This has also been a channel through which wider messages about past coastal changes, environmental damage and current threats can be communicated.

\section{SCHARP Results and Legacy}

The ShoreDIG projects presented above are diverse in the type of site they studied, the methods employed and in the legacies they have created. Beyond simply recording heritage and saving information, all projects aimed to produce a legacy that highlighted locally-valued heritage and explained threats. Those discussed here have both tangible and intangible outputs. Displays in heritage centres local to Loch Fleet and Findhorn Bay explain the fishing heritage of the area, the formation of the boat graveyards and the pressures which led to the abandonment of the activity which had once been the driving force behind the communities' existence. One exhibition tells the story of the site, using the community's historic photographs as a means of building the connection between the past and the present. In Orkney, the physical reconstruction of the Bronze Age structures is associated with interpretation at the neighbouring heritage centre. This describes the site's form and function, but also explores the environment in which the site was originally built and used, explaining what it can tell us about the past environment and changes it underwent, and the processes affecting the area today, which led to the exposure of the structures on a beach and subsequent discovery and investigation. The 4D Wemyss Caves project celebrates the local heritage and uses novel ways to present it to an international audience, but it has also created a highly detailed and millimeter-accurate record of the entire coastline which can be used to track change and as a tool for future researchers. The website presents to a global audience not only the unique sculptures but also the past environmental change the area has experienced and explores the currents threats and challenges it faces.

SCHARP's work on eroding heritage has achieved a range of diverse outcomes for Scotland's vulnerable coastal heritage. Firstly, as a result of the community partnership ShoreDIG projects, archaeologically important information has been rescued at each of one of the locally-valued sites. Each project has undertaken scientifically rigorous, academically valuable research at threatened sites which are now better understood. Thus, the project has demonstrated that broader archaeological research questions can be addressed by undertaking work at sites which are being destroyed.

Many of these sites, however are also archives of information about the wider past, and not only about human history. Projects such as Meur have rescued information that would otherwise have been lost to the sea, and the remarkable body of evidence recovered from the waterlogged deposits in these prehistoric structures will be able to tell us so much about the island's past landscape, environment and climate. The data contained within such sediments and structures can inform much wider questions about environmental history, past ecosystems and climate, as well as showing how societies responded and adapted to past change (IHOPE 2015) and some of the lessons may be applied to modern environmental change and current challenges.

More broadly than the information contained within specific individual sites, SCHARP has also created an up to date picture of Scotland's coastal archaeological resource. The records of archaeological sites created by the project are recent, robust observed data which can be used to validate computer models of coastal susceptibility to erosion and thus contribute to better informed management of the coast in the future. Long-term ongoing monitoring of those sites which have been identified as most vulnerable can turn them into a network of observational points which will inform our understanding of longer term coastal change and climate impacts.

A further result of the project is the increased community engagement with the challenges of coastal erosion and climate change. Public involvement was a core aim of SCHARP; communities are well-placed to work on vulnerable coastal sites, with knowledge not only of their local heritage, but also of the dynamics of the coast; how it has changed in the recent past and how weather and coastal processes impact their area. Local value was also a central factor in selecting priority sites 
for further action, making use of community perceptions of importance alongside judgements of archaeological significance to target resources at vulnerable heritage. By involving the public at every level of work, from site prioritisation to fieldwork, strong partnerships were built between communities and professionals. The success of the project in local engagement is largely a reflection of a genuine need; volunteers recognised the purpose behind the project which their contribution addressed (Hambly 2017b). In turn, through their involvement, they are also more aware of coastal process and environmental change through observing their effects at locally valued sites.

This legacy that SCHARP has had in the community is a further important outcome of the project. ShoreUPDATE raised awareness of vulnerable heritage sites on the coast; and ShoreDIG projects gave volunteers the opportunity to be practically involved. Community engagement with heritage was strengthened, but through surveying monuments and undertaking work at sites damaged by coastal processes, volunteers have also developed a stronger understanding of coastal environments and the processes impacting them.

\section{Discussion}

Erosion and coastal change are natural processes, but will be exacerbated by climate change and these challenges are faced by coastal communities around the globe. The loss of heritage sites is a single example of threat they pose. The examples from the Scottish coast presented here aimed to address the loss of archaeological sites, and the information contained within them, but also to contribute to broader understanding of the processes driving coastal change.

The approach in Scotland is turning thinking about erosion. Rather than regarding it as a problem, the projects are creating opportunities. The involvement of volunteers in mitigating the impact of climate threats at heritage sites has strengthened local appreciation of heritage, discoveries and threats. As this knowledge cascades through communities, the perceived value of the sites is also raised, and awareness of the impacts and challenges of current environmental change is increased.

Involving communities in taking action at threatened sites means that archaeological heritage is able to communicate key messages about environmental change. Coastal sites being damaged or at risk of loss are also places where we can learn about the past and about current and future environmental change. By using locally-valued eroding archaeological sites to tell stories about human history and to explore how the environment and climate have changed, modern changes and challenges can be better understood. Such sites can contain evidence of how past societies experienced and responded to changes in their environment from which we can learn about past strategies of adaptation and resilience. By observing the impacts of climate change on locally-valued coastal heritage, modern communities have become more aware of current processes impacting their local environment.

Exploring the stories contained within these sites thus contributes to modern understanding and debate about climate change. Increased understanding amongst communities of the processes and impacts of environmental change can contribute to an environmentally aware and active public. As discussed by Rockman and Maase (2017) effective communication about the value of heritage and the environmental threats it faces can make significant contributions towards enacting global agreement on climate change. In Scotland, working at eroding heritage sites has become a mechanism for communicating these messages and promoting action.

Erosion, coastal change and the loss of assets to the sea are global problems, but when their impact is observable and recordable at a local scale, and on locally or nationally-valued heritage assets, the problems can be more fully understood by the public. Observing such climate impacts at coastal archaeological sites creates a visible demonstration of current threats. Recording the manifestations of climate change at places that the public cares about can raise awareness of past change and bring into focus current and future challenges. Coastal heritage can thus act as a local lens through which an international problem can be examined, and so can contribute to an actively engaged population. 


\section{Conclusions}

The challenges facing Scotland's coasts are not unique; and the approaches adopted here can be applied to other coastlines, to other heritage, and a range of different assets threatened by environmental change around the world. Some of the approaches developed in Scotland are now being adopted internationally, allowing lessons learned at the Scottish coast to contribute to other countries' responses to this global challenge.

Since its establishment, SCAPE has developed mechanisms to address the issue of loss of heritage sites to coastal processes, and to integrate communities with this work. The creation of accurate records of heritage sites by volunteers around the Scottish coastline has generated a useful dataset on the condition and susceptibility of the wider coast to erosion. Although focused on heritage assets, this observed data is also of use for a variety of other purposes. Vulnerable archaeological sites can act as observational nodes at which the impacts of coastal change can be observed and recorded, and long-term change can be monitored. These datasets can contribute to work by geologists, geomorphologists, and coastal managers. Models of coastal vulnerability to erosion are being developed and used to inform strategic planning for the coast, to identify vulnerable areas which will require support and to develop future management and adaptation plans. The heritage data collected through SCHARP constitutes an up to date record of coastal condition, which, by virtue of local involvement, can be regularly updated by trained observers. Such robust datasets can be used to validate and improve computer models and thus contribute to improved coastal management in the future.

In Scotland, as in many places around the world, the scale of the problem outpaces available resources, meaning that decisions must be taken to prioritise action. By integrating local perceptions of value with professional judgments of significance, SCHARP has implemented one method of prioritizing action and targeting limited resources which can be applied elsewhere and to other assets. Undertaking work in a truly collaborative spirit has developed strong partnerships with communities and other stakeholders. This approach has engendered a sense of stewardship and communicated messages about the importance of heritage, the risk of loss and challenges facing coastlines and coastal communities. Heritage has thus become one means of illustrating the impact of climate-driven coastal and environmental change, raising awareness of threats. Public awareness is a key element in developing successful strategies for future adaptation and resilience; and by using locally-valued heritage assets as a mechanism for initiating community projects, messages of environmental change, are communicated, leading to understanding about global challenges being strengthened.

Acknowledgments: The authors would like to thank all the volunteers around Scotland who have contributed their time and expertise to the project; and the Heritage Lottery Fund, Historic Environment Scotland, the Crown Estate, the University of St Andrews and Fife Council for their support of SCHARP and the ShoreDIGs.

Author Contributions: The concepts, ideas and results presented in this paper are the product of longstanding research by all three authors; Ellie Graham is the lead writer of the manuscript.

Conflicts of Interest: The authors declare no conflict of interest.

\section{References}

Angus, Stewart, Jim D. Hansom, and Alistair Rennie. 2011. Habitat change on Scotland's coasts. In The Changing Nature of Scotland. Edited by Susan J. Marrs, Simon Foster, Catriona Hendrie, Edward C. Mackey and Des B. A. Thompson. Edinburgh: The Stationery Office, pp. 183-98.

Ashmore, Patrick J. 1994. Archaeology and the Coastal Zone: Towards a Historic Scotland Policy. Edinburgh: Historic Scotland.

Cassar, May. 2005. Climate Change and the Historic Environment. London: Centre for Sustainable Heritage, University College London.

CCC (Committee on Climate Change). 2016a. UK Climate Change Risk Assessment 2017: Evidence Report, Summary for Scotland. London: Committee on Climate Change. 
CCC (Committee on Climate Change). 2016b. UK Climate Change Risk Assessment 2017: Chapter 3: Natural Environment and Natural Assets. London: Committee on Climate Change.

Council of Europe. 1992. European Convention on the Protection of the Archaeological Heritage (Revised). Valetta: Council of Europe.

Crawford, John, Glen McIntosh, and Ron Stewart. 2010. Sail \& Steam Revisited. Lossiemouth: Buckie \& District Fishing Heritage Centre.

Dawson, Tom. 2008. A Review of the Coastal Zone Assessment Surveys of Scotland. Internal Report for Historic Scotland; Edinburgh: Historic Scotland.

Dawson, Tom. 2010. A System for Prioritising Action at Archaeological Sites Recorded in the Coastal Zone Assessment Surveys 1996-2009. Internal Report for Historic Scotland; Edinburgh: Historic Scotland.

Dawson, Tom. 2015. Taking the middle path to the coast: How community collaboration can help save threatened sites. In The Future of Heritage as Climates Change: Loss, Adaptation and Creativity. Edited by David Harvey and Jim Perry. London: Routledge, pp. 248-67.

Dawson, Tom, Joanna Hambly, and Ellie Graham. 2017. A central role for communities: Climate change and coastal heritage management in Scotland. In Public Archaeology and Climate Change. Edited by Tom Dawson, Courtney Nimura, Elías Lopez-Romero and Marie-Yvane Daire. Oxford: Oxbow Books, pp. 50-68.

Department of the Environment. 1990. Planning Policy Guidance Note 16 (PPG16) Archaeology and Planning; London: Department of the Environment.

Dorian, Nancy. 1985. The Tyranny of Tide: An Oral History of the East Sutherland Fisherfolk. Ann Arbour: Karoma Publishers.

Doughton, Lauren. 2014. 'A most Curious Class of Small Cairn': Reinterpreting the Burnt Mounds of Shetland. Ph.D. dissertation, University of Manchester, Manchester, UK.

Fraser, Shannon M., Simon Gilmour, and Tom Dawson. 2003. Shorewatch: Monitoring Scotland's coastal heritage. In Coastal Archaeology and Erosion in Scotland. Edited by Tom Dawson. Edinburgh: Historic Scotland, pp. 197-202.

Garrow, Duncan, and Fraser Sturt. 2017. Neolithic Stepping Stones: Excavation and Survey within the Western Seaways of Britain, 2008-2014. Oxford: Oxbow Books.

Gordon, John, ed. 1999. The New Statistical Account of Scotland/by the Ministers of the Respective Parishes, under the Superintendence of a Committee of the Society for the Benefit of the Sons and Daughters of the Clergy. Volume 13. Edinburgh: University of Edinburgh, Glasgow: University of Glasgow, First published in 1845. Edinburgh: Blackwoods and Sons; The Statistical Accounts of Scotland online service: http:/ / stataccscot.edina.ac.uk/ (accessed on 24 June 2017).

Graham, Ellie, and Joanna Hambly. 2017a. Loch Fleet Boat Graveyard, Unpublished Data Structure Report.

Graham, Ellie, and Joanna Hambly. 2017b. Findhorn Bay Boat Graveyard, Unpublished Data Structure Report.

Graham, Ellie, Joanna Hambly, and Tom Dawson. forthcoming. Scotland's eroding heritage: A collaborative response to the impact of climate change. Archaeological Review from Cambridge 32. In press.

Hambly, Joanna. 2017a. A Review of Heritage at Risk from Coastal Processes in Scotland. Internal Report for Historic Environment Scotland. Edinburgh: Historic Environment Scotland.

Hambly, Joanna. 2017b. SCHARP: Four Transformative Years. Internal Unpublished Report for Historic Environment Scotland and the Heritage Lottery Fund.

Hambly, Joanna, M. Abbott, and Mike Arrowsmith. forthcoming. How a community-based digital heritage project may help us imagine the circumstances of symbolic Pictish carvings in the Wemyss Caves, Scotland. In Between Worlds: Understanding Ritual Cave Use in Later Prehistory. Edited by Lindsey Büster, Eugène Warmenbol and Dimitrij Mlekuž. New York: Springer.

Hansom, Jim D., George Lees, Derek J. McGlashan, and S. John. 2004. Shoreline Management Plans and Coastal Cells in Scotland. Coastal Management 32: 227-42. [CrossRef]

Hedges, John. 1975. Excavations of two Orcadian burnt mounds at Liddle and Beaquoy. Proceedings of Society of Antiquaries of Scotland 106: 39-98.

Historic Environment Scotland. 2014. Scotland's Archaeology Strategy. Edinburgh: Historic Environment Scotland.

Historic Scotland. 1996. Coastal Zone Assessment Survey: Historic Scotland Archaeological Procedure Paper 4. Edinburgh: Historic Scotland. 
IHOPE (Integrated History and Future of People on Earth). 2015. Global Environmental Change Threats to Heritage and Long Term Observing Networks of the Past. IHOPE. Available online: http:/ / ihopenet.org/globalenvironmental-change-threats-to-heritage-and-long-term-observing-networks-of-the-pas / (accessed on 19 August 2017).

Jowell, Tessa. 2005. Better Places to Live-Government, Identity and the Value of the Historic and Built Environment. London: Department for Culture, Media and Sport.

Keers, Geurt, Hans van der Reijden, and Hans van Rossum. 2011. Planning Archaeology: A Synthesis of the Thematic Sub-Reports. Amsterdam: Ministry of Education.

Le Bon, Elizabeth. 1992. The Jonathan's Cave boat carving: A question of authenticity? International Journal of Nautical Archaeology 21: 337-42. [CrossRef]

Moore, Hazel, and Graeme Wilson. 1999. Food for Thought; A survey of burnt mounds of Shetland and excavations at Tangwick. Proceedings of the Society of Antiquaries of Scotland 129: 203-37.

Moore, Hazel, and Graeme Wilson. 2001. Report on Excavations at Cruester Burnt Mound, Bressay, Shetland. Edinburgh: EASE Archaeology.

Moore, Hazel, and Graeme Wilson. 2008. Bronze Age Bressay! Report on a Further Season of Excavation at Cruester Burnt Mound, Bressay, Shetland 2008. Edinburgh: EASE Archaeology.

Moore, Hazel, and Graeme Wilson. 2014. Ebbin Shores: Survey and Excavation of Coastal Archaeology in Shetland 1995-2008. Historic Scotland Archaeology Report No. 8; Edinburgh: Historic Scotland.

National Coastal Change Assessment. 2016. Scotland's Dynamic Coast. Available online: www.dynamiccoast.com (accessed on 30 October 2017).

National Historic Ships UK. 2017. National Register of Vessels. Available online: http://www. nationalhistoricships.org.uk/ (accessed on 20 August 2017).

Pickard, Robert, ed. 2001. Policy and Law in Heritage Conservation. London: Spon Press.

Reid, Joseph. 2012. The Mighty Zulu. Lossiemouth: Buckie and District Fishing Heritage Centre.

Rockman, Marcy, and Jakob Maase. 2017. Every place has a climate story: Finding and sharing climate change stories with cultural heritage. In Public Archaeology and Climate Change. Edited by Tom Dawson, Courtney Nimura, Elías Lopez-Romero and Marie-Yvane Daire. Oxford: Oxbow Books, pp. 107-14.

SCAPE Trust. 2012. Scotland's Coastal Heritage at Risk Project. Available online: http://www.scharp.co.uk/ (accessed on 17 July 2017).

Scottish Government. 2014a. Scottish Planning Policy. Edinburgh: Scottish Government.

Scottish Government. 2014b. Our Place in Time-The Historic Environment Strategy for Scotland. Edinburgh: Scottish Government.

SNH. 2000a. Guidance: Coastal Erosion and Defence. Policy Guidance Note 00/03. Edinburgh: Scottish Natural Heritage.

SNH. 2000b. A Guide to Managing Coastal Erosion in Beach/Dune Systems. Edinburgh: Scottish Natural Heritage.

Sutherland, David. 2015. The Scottish Continental Herring Trade 1810-1914. Available online: http:/ / www. scottishherringhistory.uk/ (accessed on 23 May 2017).

Tanner, Matthew. 2010. Scottish Fishing Boats. Oxford: Shire Publications.

Tindley, Annie. 2010. The Sutherland Estate, 1850-1920: Aristocratic Decline, Estate Management and Land Reform. Edinburgh: Edinburgh University Press.

Toolis, Ronan. 2009. Excavation of a burnt mound at Meur, Sanday, Orkney. Scottish Archaeological Journal 29: 31-49. [CrossRef]

(C) 2017 by the authors. Licensee MDPI, Basel, Switzerland. This article is an open access article distributed under the terms and conditions of the Creative Commons Attribution (CC BY) license (http:/ / creativecommons.org/licenses/by/4.0/). 